\title{
SURFACE WATER QUALITY ASSESSMENT AND MAPPING OF PERIYAR RIVER USING CANADIAN COUNCIL OF MINISTERS OF THE ENVIRONMENT WATER QUALITY INDEX METHOD
}

\author{
P.C. Aneesh ${ }^{1}$, Roy M Thomas ${ }^{2}$ \\ ${ }^{1}$ Research Scholar, Department of Civil Engineering, School of Engineering, \\ Cochin University of Science and Technology, Kerala, India \\ ${ }^{2}$ Professor, Department of Civil Engineering, School of Engineering, Cochin University of \\ Science and Technology, Kerala, India
}

\begin{abstract}
In the view of higher demand of fresh water, water quality assessment has to be done periodically. In this study, the water quality of the Periyar River, which is located in Kerala, India is evaluated. River Periyar is considered as the lifeline of Kerala. Twentyfive percentage of Kerala's industries are located at the banks of Periyar River. Due to the disposal of untreated or partially treated waste in to the river, the water quality of the river changes. In order to make the water fit for drinking purpose, the water quality parameters should lie in permissible limit. The water quality data measurement results obtained from CPCB during the year 2019 was used as the input data. Water quality was evaluated by Canadian Council of Ministers of the Environmental Water Quality Index (CCME WQI) method. QGIS was adopted to map the WQI values. IDW interpolation technique was adopted for mapping. WQI of station numbers SS:2333 and SS:18 showed almost good WQ compared to other sampling stations as it is not an industrialized area. The flood happened in Kerala influenced a lot in the water quality. Station number SS:2333 showed a WQI of 83.8, which is the largest value obtained during the entire course of study. WQI of station number SS:17 is obtained as 51.36, which is the lowest among all results. From the study it is evident that CCME WQI is a good indicator for water quality assessment and can be used for similar type studies.
\end{abstract}

Keywords: CCME Water Quality Index, GIS mapping, IDW interpolation technique, Periyar River, Water Quality

Cite this Article: P.C. Aneesh and Roy M Thomas, Surface Water Quality Assessment and Mapping of Periyar River using Canadian Council of Ministers of the Environment Water Quality Index Method, International Journal of Civil Engineering and Technology (IJCIET), 12(8), 2021, pp. 57-65.

https://iaeme.com/Home/issue/IJCIET?Volume $=12 \&$ Issue $=8$ 


\section{INTRODUCTION}

Water is an inevitable item for all living organism in the world. Though we are having large number of water source, fresh water scarcity is the big issue that the entire world facing nowadays. Water quality analysis is an important part of environmental monitoring. If water quality of the river is poor, it affects aquatic life and surrounding ecosystem. Water quality monitoring can be defined as the sampling and analysis of constituents of water and environmental conditions. These may include the constituents found naturally in water that can nevertheless be affected by human sources, such as dissolved oxygen, bacteria, and nutrients.

Periyar River is one of the few perennial rivers in the Kerala state and it provides water for several major towns. The Periyar has high influence in the economy of Kerala. It generates a significant proportion of Kerala's electrical power and flows along a region of industrial and commercial activity. Periyar River is getting polluted due to various anthropogenic activities. In fact, Periyar, one of the most polluted rivers in the state, has also been observed to be very acidic especially in the industrial belt of Eloor. Water quality (WQ) is defined as biological, chemical, and physical characteristics of water in connection with intended use(s) and a set of standards [1-3]. Quality of the water can be evaluated by a single parameter for certain objective or by a number of critical parameters selected carefully to represent the pollution level of the water body of concern and reflect its overall water quality status. However, since no individual parameter can express the WQ sufficiently, the WQ is normally assessed by measuring a broad range of parameters[4]. A quality index is a unit less number that assigns a quality value to an aggregate set of measured parameters[5]. So, the water quality index can be defined as a single numeric score that describes the WQ condition at a particular location in a specific time[6].

The water quality can be assessed on the basis of several characteristics, each of which beyond specified limits, may render the water unfit for use for particular purpose. Even though many assessment methods are available, water quality indexing (WQI) is the widely accepted one. The water quality index is an important tool to understand the water quality in urban, rural and industrial area. WQI is represented as an index reflecting the composite influence of different water quality parameters which is considered and taken for calculation of water quality index. Water quality index was initially proposed by the scientists Horton and Brown. In further studies multiplicative form of the index were assigned based on a subjective opinion and critical analysis of the authors [7-12].

The water quality index has been designed to evaluate suitability of water for specific uses. The main objective of calculation of these indices is to compare some water quality variables (WQVs) with WQ standards so that the indices will reveal the variable(s) exceeding the standards as well as the frequency and extent of exceedance. These indices offer several advantages including representation of measurements on many variables varying in measurement units in one dimension, thus establishing a criterion for tracking changes in water quality over time and space and simplifying communication of the monitoring results[13]. Besides, when pollution is identified and remedial action is taken, the water quality index can be used to track and follow- up any incremental water quality improvement trends to determine effectiveness of stream restoration efforts[6].

The study on Periyar River along a stretch of Eloor area reveals the influence of WQI on water quality of Periyar River. The study was over a period of one year. Statistical analysis was conducted to assess the water quality. From the study it was evident that the water quality of that area is not up to the mark [14]. Another researcher has made an attempt to develop water quality index (WQI), using six water quality parameters $\mathrm{pH}$, dissolved oxygen, biochemical oxygen demand, electrical conductivity, nitrate nitrogen and total coliform measured at three different stations along the Sabarmati river basin from the year 2005 to 2008[15]. 
Present study focuses on the WQI and GIS mapping of Periyar River.

\section{MATERIALS AND METHODS}

\subsection{Study Area}

The Periyar River has a total length of 244 kilometers and a catchment area of 5,398 square kilometers, of which 5,284 square kilometers is in Kerala and 114 square kilometers is in Tamil Nadu. Location map is shown in figure 1. Major pollution occurs at the industrial belt of Kochi.

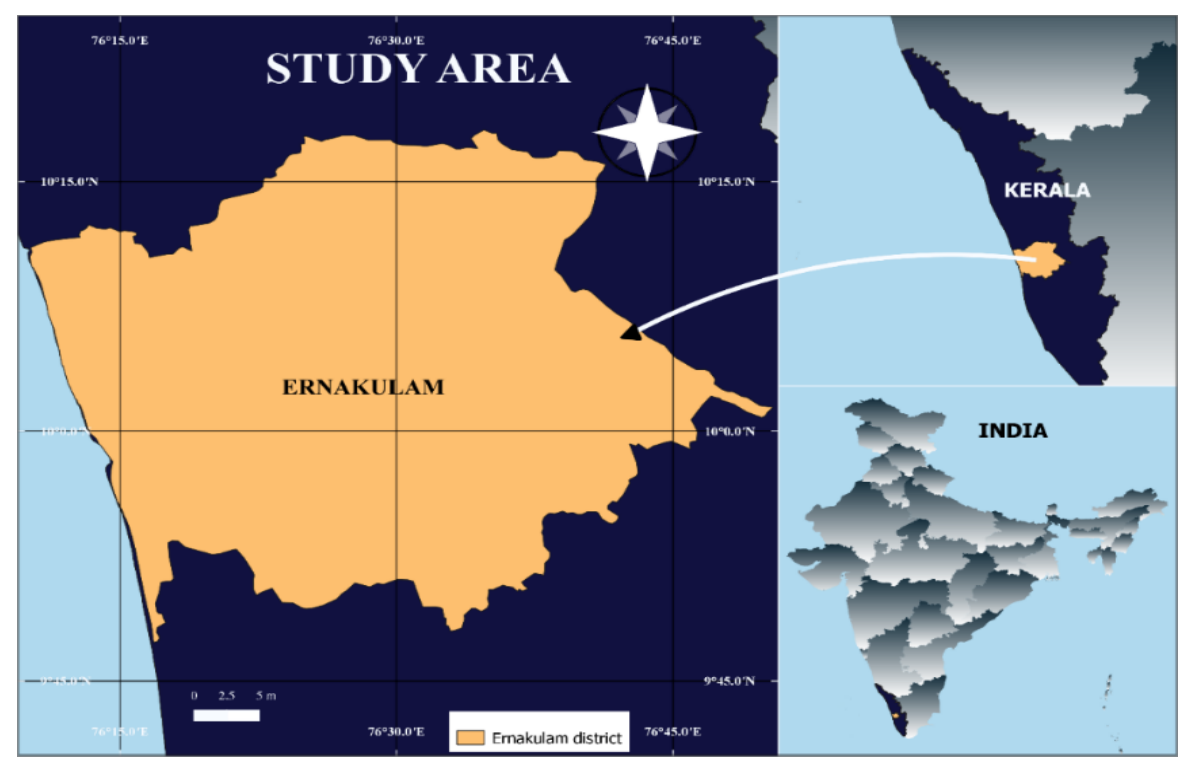

Figure 1. Study Area

\subsection{Data Collection}

Water quality data was collected from ENVIS-CPCB in the year 2019. WQ of seven sampling stations in Kerala state was analysed. Majority of the sampling points are located in industrial belts of Kerala. Location details of sampling stations are shown as Table 1.

Table 1. Location details of sampling stations

\begin{tabular}{llll}
\hline \multicolumn{1}{c}{ Station Code } & \multicolumn{1}{c}{ Station Name } & \multicolumn{1}{c}{ Latitude } & \multicolumn{1}{c}{ Longitude } \\
\hline SS:17 & Alwaye-Eloor & 10.066 & 76.298991 \\
\hline SS:18 & Kalady & 10.16049 & 76.441474 \\
\hline SS:1338 & SDP & 10.11366 & 76.350304 \\
\hline SS:2333 & Muppathadam & 10.0825 & 76.320865 \\
\hline SS:2334 & Pathalam & 10.07584 & 76.309088 \\
\hline SS:2335 & Kalamassery & 10.06622 & 76.324178 \\
\hline SS:2336 & Purappillikadavu & 10.1442 & 76.285363 \\
\hline
\end{tabular}

Water Quality analysis results are tabulated as table 2 and table 3. Eight parameters (Temperature, Dissolved Oxygen, Electrical Conductivity, Biochemical Oxygen Demand, pH, Nitrate + Nitrite, Faecal Coliform, Total Coliform) were considered for the study. Standard water quality analysis procedure was adopted for sampling and testing. Minimum and maximum values of the selected parameters were used for the further analysis. Majority of these parameters are directly affects the water quality of the river. 
Surface Water Quality Assessment and Mapping of Periyar River using Canadian Council of Ministers of the Environment Water Quality Index Method

Table 2. Water Quality results (Temperature, $\mathrm{pH}, \mathrm{DO}$ and Conductivity)

\begin{tabular}{lcccccccc}
\hline \multirow{2}{*}{$\begin{array}{c}\text { Station } \\
\text { code }\end{array}$} & \multicolumn{2}{c}{$\begin{array}{c}\text { Temperature } \\
\left({ }^{\circ} \mathbf{C}\right)\end{array}$} & \multicolumn{2}{c}{$\begin{array}{c}\text { Dissolved } \mathbf{O}_{2} \\
(\mathbf{m g} / \mathbf{l})\end{array}$} & \multicolumn{2}{c}{ pH } & \multicolumn{2}{c}{$\begin{array}{c}\text { Conductivity } \\
(\boldsymbol{\mu m h o s} / \mathbf{c m})\end{array}$} \\
\cline { 2 - 9 } & Min & Max & Min & Max & Min & Max & Min & Max \\
\hline SS:17 & 27.0 & 32.0 & 4.4 & 9.6 & 6.6 & 7.7 & 90 & 33000 \\
SS:18 & 25.0 & 30.0 & 4.0 & 8.2 & 6.6 & 7.6 & 32 & 56 \\
SS:1338 & 24.0 & 31.0 & 4.8 & 7.7 & 4.1 & 7.3 & 38 & 78 \\
SS:2333 & 24.0 & 33.0 & 4.5 & 7.9 & 6.8 & 7.7 & 35 & 92 \\
SS:2334 & 24.0 & 31.0 & 4.7 & 9.1 & 6.5 & 7.2 & 44 & 29000 \\
SS:2335 & 25.0 & 31.0 & 0.9 & 7.4 & 6.3 & 7.3 & 41 & 135 \\
SS:2336 & 26.0 & 31.0 & 5.3 & 7.2 & 6.7 & 7.7 & 49 & 9600 \\
\hline
\end{tabular}

Table 3. Water Quality results (BOD, Nitrate + Nitrite, FC and TC)

\begin{tabular}{lllllllll}
\hline \multirow{2}{*}{$\begin{array}{c}\text { Station } \\
\text { code }\end{array}$} & \multicolumn{2}{c}{ BOD $(\mathbf{m g} / \mathbf{l})$} & \multicolumn{2}{c}{$\begin{array}{c}\text { Nitrate N }+ \\
\text { Nitrite N (mg/l) }\end{array}$} & \multicolumn{2}{c}{$\begin{array}{c}\text { Fecal Coliform } \\
\text { (MPN/100ml) }\end{array}$} & \multicolumn{2}{c}{$\begin{array}{c}\text { Total Coliform } \\
\text { (MPN/100ml) }\end{array}$} \\
\cline { 2 - 9 } & Min & Max & Min & Max & Min & Max & Min & Max \\
\hline SS:17 & 0.3 & 2.8 & 0.07 & 1.58 & 170 & 12000 & 400 & 43000 \\
SS:18 & 0.5 & 2.6 & 0.01 & 1.19 & 170 & 3800 & 460 & 7000 \\
SS:1338 & 0.4 & 2.1 & 0.01 & 2.63 & 580 & 7000 & 1200 & 7900 \\
SS:2333 & 0.1 & 1.6 & 0.01 & 0.59 & 240 & 3500 & 1100 & 5400 \\
SS:2334 & 0.2 & 2.9 & 0.01 & 2.62 & 400 & 4700 & 1400 & 26000 \\
SS:2335 & 0.3 & 2.4 & 0.01 & 0.52 & 350 & 4600 & 1700 & 16000 \\
SS:2336 & 0.1 & 2.8 & 0.05 & 1.12 & 40 & 2700 & 110 & 7000 \\
\hline
\end{tabular}

Minimum and maximum observed values of water quality parameters are represented as figure 2 and figure 3 . Some WQ parameters were not to be within permissible limit.
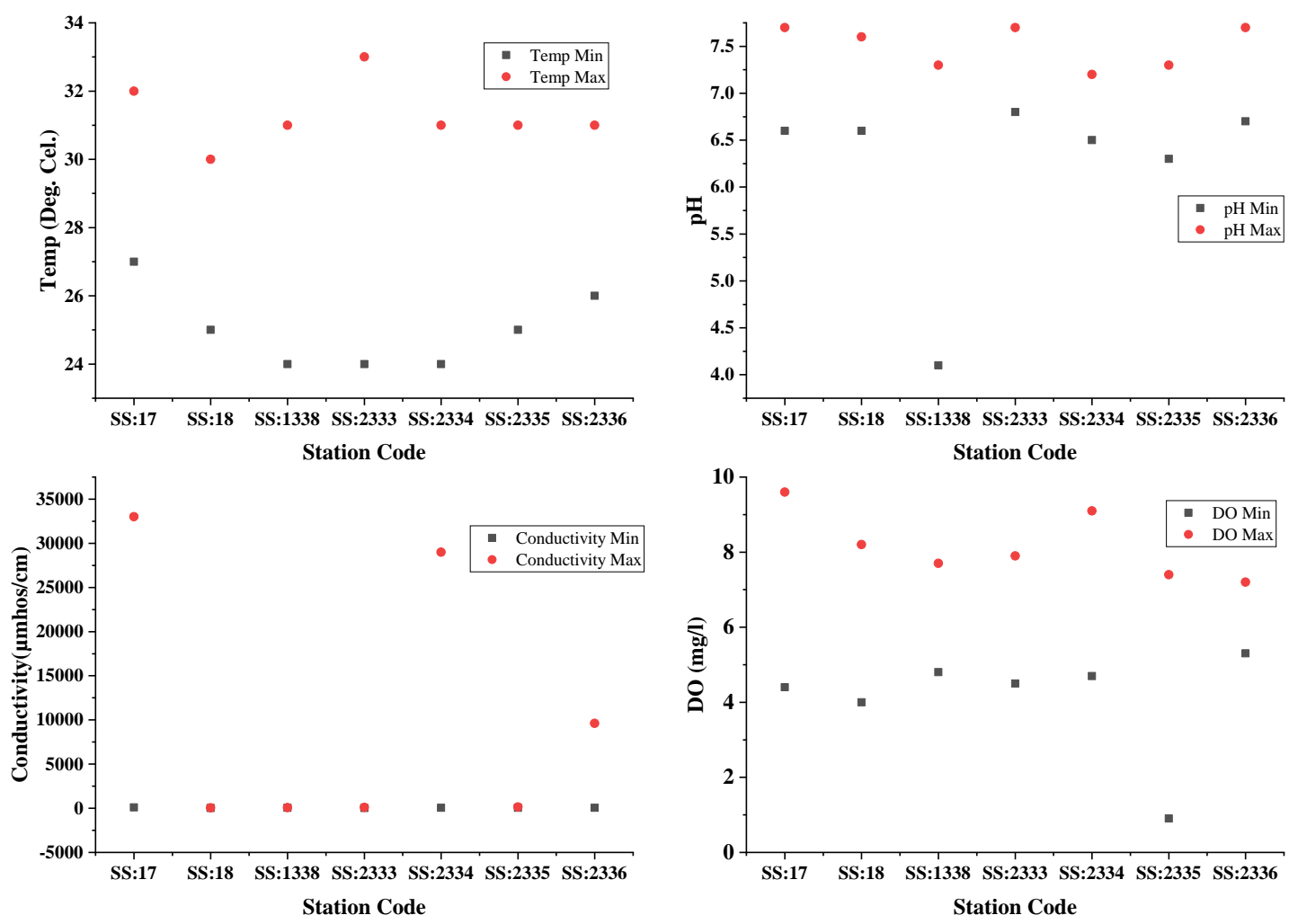

Figure 2. Graphical representation of WQ parameters (Temperature, $\mathrm{pH}, \mathrm{DO}$ and Conductivity) 

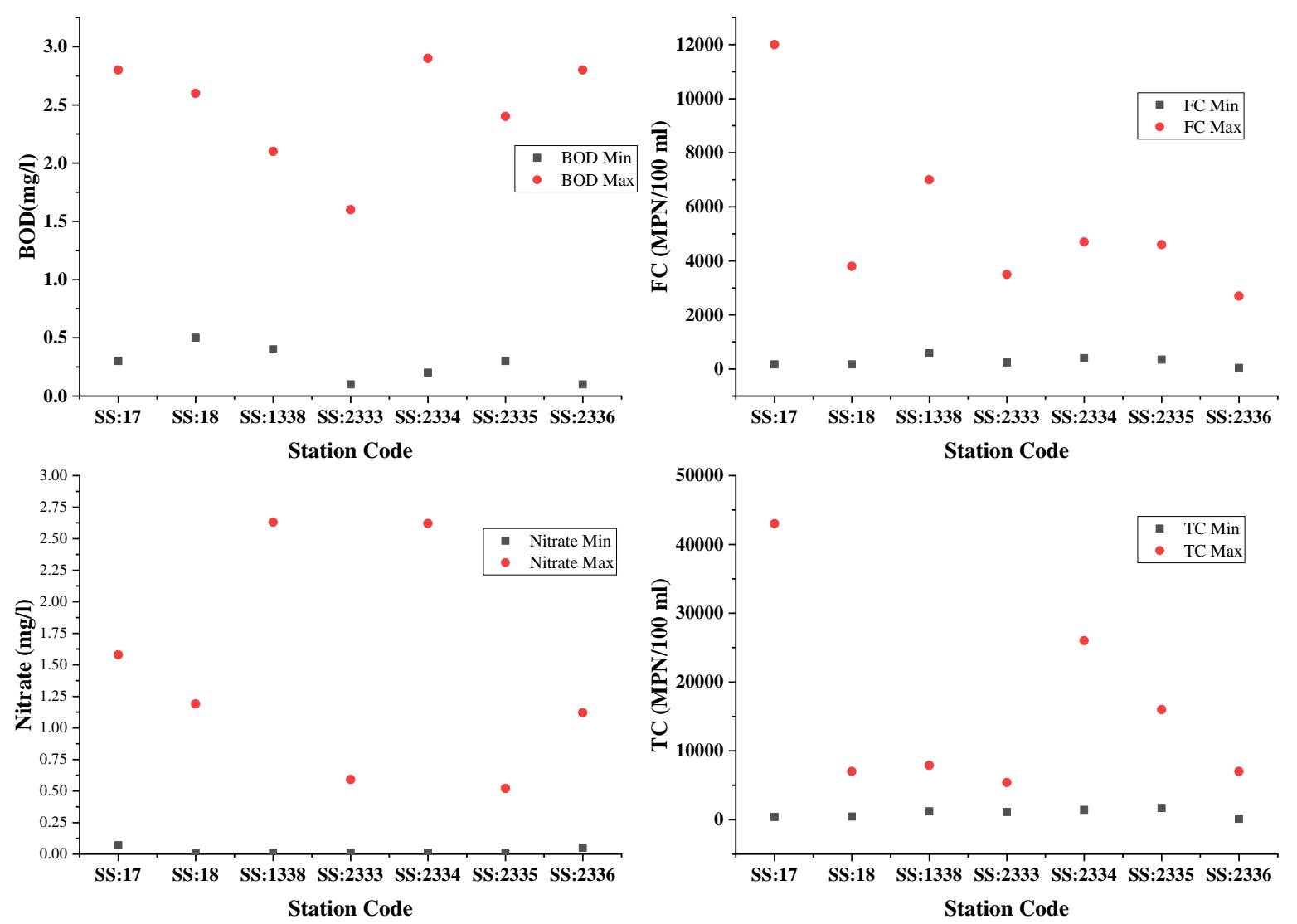

Figure 3. Graphical representation of WQ parameters (BOD, Nitrate + Nitrite, FC and TC)

\subsection{Water Quality Index}

The index developed by Canadian Council of Ministers of the Environment Water Quality Index (CCME WQI) is considered as an efficient way to summarise complex data. Conceptual frame work to find CCME WQI is explained below.

$F_{1}$ (Scope): Scope means the extent of water quality guideline non-compliance over the time period of interest. which means the number of parameters whose objective limits are not met.

$$
F_{1}=\left(\frac{\text { Number of failed variables }}{\text { Total Number of variables }}\right) \times 100
$$

Where, the variables indicate those water quality parameters whose threshold limits are specified and observed values at the sampling sites are available for the index calculation.

$F_{2}$ (Frequency): The frequency means the results with which the objectives are not met, which represents the percentage of individual tests that do not meet the objectives.

$$
F_{2}=\left(\frac{\text { Number of failed tests }}{\text { Total Number of tests }}\right) \times 100
$$

$F_{3}$ (Amplitude): Amplitude means the amount by which the objectives are not met that represents the amount by which the failed test values do not meet their objectives, which is calculated in three steps.

The number of times by which an individual concentration is greater than (or less than, when the objective is a minimum) the objective is termed an excursion.

When the test value must not exceed the objective: 
Surface Water Quality Assessment and Mapping of Periyar River using Canadian Council of Ministers of the Environment Water Quality Index Method

Excursion $_{i}=\left(\frac{\text { Failed test Value }_{i}}{\text { Objective }_{j}}\right)-1$

For the cases in which the test value must not fall below the objective:

Excursion $_{i}=\left(\frac{\text { Objective }_{j}}{\text { Failed Test Value }_{i}}\right)-1$

The collective amount, by which the individual tests are out of compliance, is calculated summing the excursions of individual tests from their objectives and then dividing the sum by the total number of tests.

$$
n s e=\frac{\sum_{i=1}^{n} \text { excursion }_{i}}{\text { Number of test }}
$$

$\mathrm{F}_{3}$ is then calculated by an asymptotic function that scales the normalized sum of the excursions from objectives (nse) to yield a value between 0 and 100 .

$$
F_{3}=\left(\frac{n s e}{0.01 \text { nse }+0.01}\right)
$$

Water Quality index can be calculated as follows.

$\boldsymbol{C C M E} \boldsymbol{W} \boldsymbol{Q I}=100-\left(\frac{\sqrt{\mathrm{F}_{1}{ }^{2}+\mathrm{F}_{2}{ }^{2}+\mathrm{F}_{3}{ }^{2}}}{1.732}\right)$

It's very essential to rate the water quality after finding index. Water Quality Index has to be rated as per the standards. The interpretive description for Canadian Council of Ministers of the Environment Water Quality Index Method values is shown as table 4.

Table 4. CCME ratings, values, and descriptions (2005b).

\begin{tabular}{lcl}
\hline \multicolumn{1}{c}{ Rating } & CCME WQI Values & \multicolumn{1}{c}{ Interpretive Description } \\
\hline Excellent & $95-100$ & $\begin{array}{l}\text { Water quality is protected with a virtual absence of threat } \\
\text { or impairment; conditions very close to natural or pristine } \\
\text { levels, }\end{array}$ \\
\hline Good & $80-94$ & $\begin{array}{l}\text { Water quality is protected with only a minor degree of } \\
\text { threat or impairment; conditions rarely depart from natural } \\
\text { or desirable levels }\end{array}$ \\
\hline Fair & $60-79$ & $\begin{array}{l}\text { Water quality is usually protected but occasionally } \\
\text { threatened or impaired; conditions sometimes depart from } \\
\text { natural or desirable levels, }\end{array}$ \\
\hline Marginal & $45-59$ & $\begin{array}{l}\text { Water quality is frequently threatened or impaired; } \\
\text { conditions often depart from natural or desirable levels }\end{array}$ \\
\hline Poor & $0-44$ & $\begin{array}{l}\text { Water quality is almost always threatened or impaired; } \\
\text { conditions usually depart from natural or desirable levels }\end{array}$ \\
\hline
\end{tabular}

\section{RESULTS AND DISCUSSIONS}

\subsection{Water Quality Parameters}

Eight parameters (Temperature, DO, EC, BOD, pH, Nitrate, FC, TC) were considered as the independent parameters for the WQI. Temperature of the water body didn't influence the water quality index. FC, TC, BOD, DO, $\mathrm{pH}$ and conductivity showed significant importance in WQI. FC, TC and DO are the most significant parameters of the index as majority of the tested values were above permissible limit. 


\subsection{Water Quality Index (WQI)}

Water Quality Index was calculated from the parameters during the monsoon period of 2019. Table 5 shows the WQI value calculated by CCME method. $F_{1}$ (Scope), $F_{2}$ (Frequency)and $F_{3}$ (Amplitude) values have significant importance in WQI. Surface water quality of the river was poor in majority of sampling stations due to the flood. Majority of the sampling stations are located in industrial area. Water quality of this places are not good because of the effluent discharge to the river. Overall water quality seems to be fair in the year 2019.

Table 5. WQI value observed in all sampling stations

\begin{tabular}{cccccl}
\hline Station Code & $\mathbf{F}_{\mathbf{1}}$ & $\mathbf{F}_{\mathbf{2}}$ & $\mathbf{F}_{\mathbf{3}}$ & $\mathbf{C C M E}$ WQI & \multicolumn{1}{c}{ Rating } \\
\hline 17 & 37.5 & 18.75 & 73.064 & 51.36 & Marginal \\
18 & 25 & 12.5 & 5.43735 & 83.56 & Good \\
1338 & 37.5 & 18.75 & 15.6357 & 74.17 & Fair \\
2333 & 25 & 12.5 & 2.43902 & 83.8 & Good \\
2334 & 37.5 & 18.75 & 67.4002 & 54.17 & Marginal \\
2335 & 50 & 25 & 28.8397 & 63.68 & Marginal \\
2336 & 37.5 & 18.75 & 36 & 68.09 & Fair \\
\hline
\end{tabular}
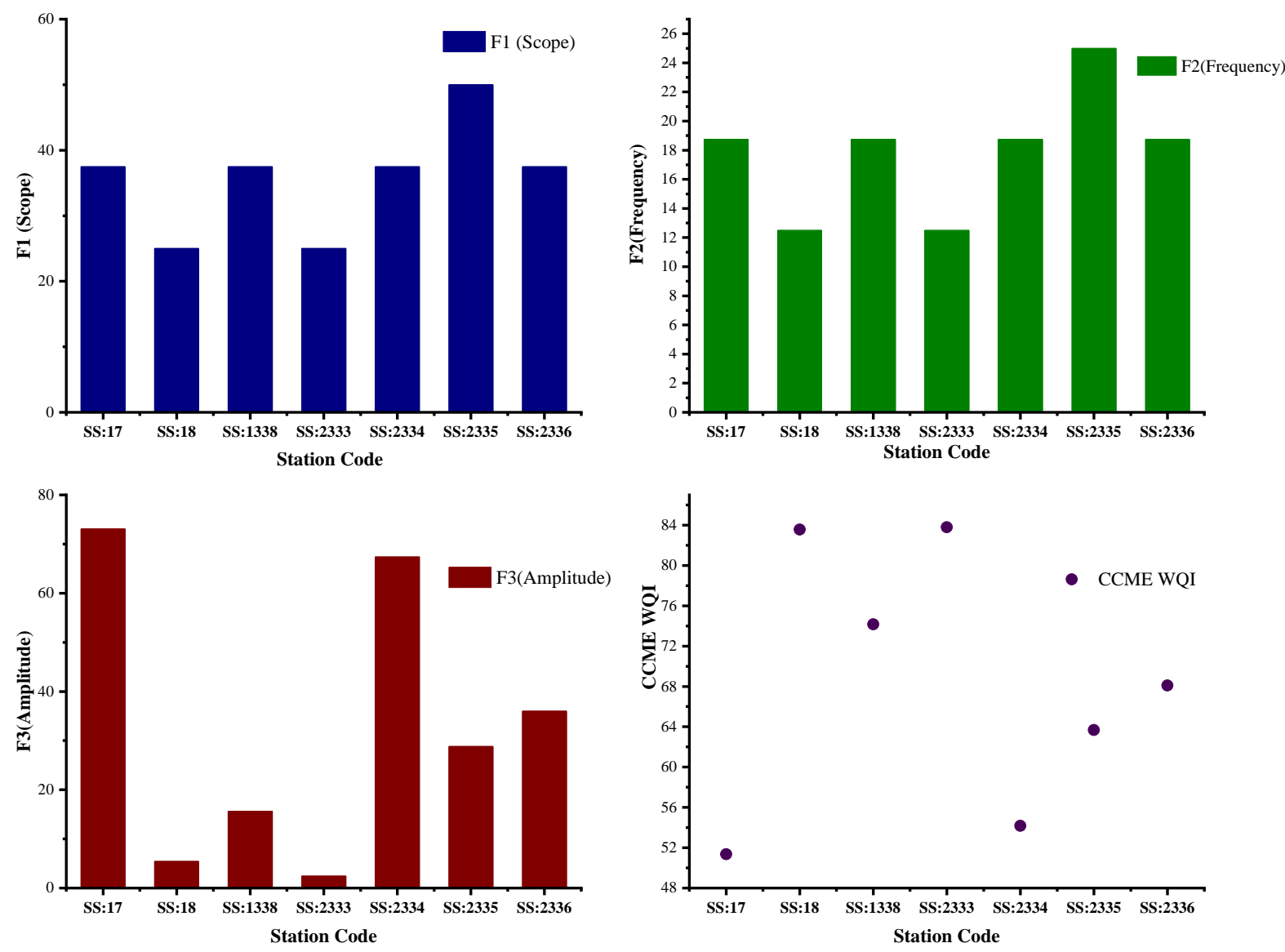

Figure. 4. Graphical representation of WQI

Water Quality is good in the sampling station SS:18 and SS:2333, since it is not an industrialized area. Graphical representation of WQI is shown as Figure 4. Similarly, WQI of SS: 17 is very low, as it is polluted heavily by industrial discharges. Direct disposal of partially treated effluent discharges will influence the quality of water body. 


\subsection{Water Quality Mapping in GIS}

WQI was given as input data for the mapping. IDW interpolation technique was adopted to map the index. Inverse Distance Weighted (IDW) is an interpolation method which estimates cell values by averaging the values of sample data points in the neighbourhood of each processing cell. For predicting a value for any unmeasured location, IDW uses the measured values details of the surrounding measured location. GIS map gives a better interpretation of water quality in surrounding areas also. Figure 5 represents the WQI map generated from QGIS.

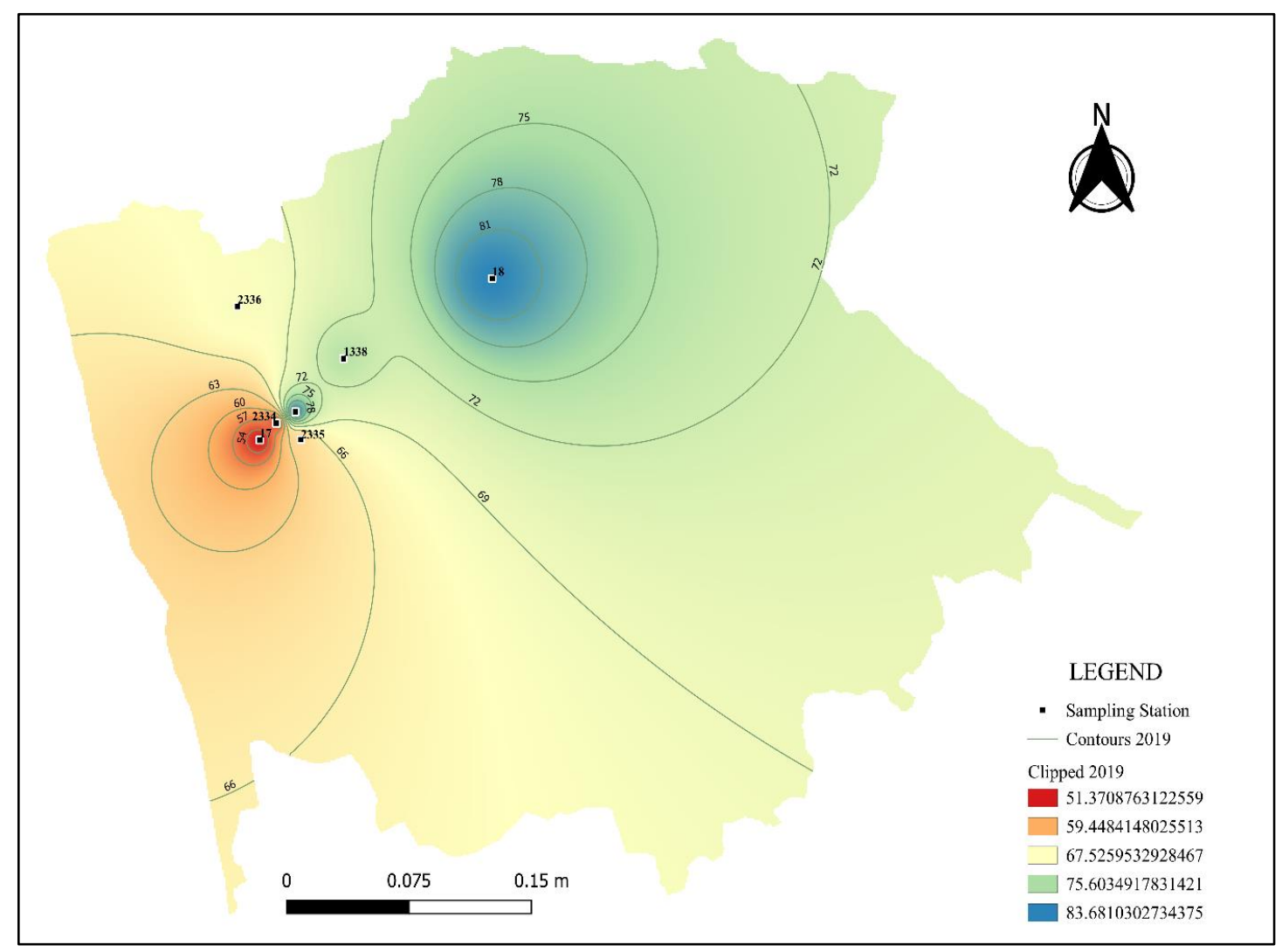

Figure 5. WQI mapping in GIS (Year: 2019)

\section{CONCLUSIONS}

This study demonstrates that the use of CCME WQI and GIS mapping together. The study could provide useful information of water quality of Periyar River. CCME WQI have the potential to assess the overall impacts of existing or proposed water quality interventions and management decisions. The WQI approach helped to categorize the water based on their physiochemical parameters and provides a composite numerical value at a defined scale. The WQI has potential for decision making and management in flag contaminate of concern, assess overall impacts of water quality interventions, communicate impacts of management and policy decisions, monitor water resource and health. The WQI output numeric values by CCME method gives the water quality status with respect to excellent to severely polluted. In this study, physicochemical parameters have been used to generate the spatial pattern of WQI for the study area. During observation it was found that CCME WQI is more reliable. Even though the CCME WQI is quick and reliable but they do not replace the detailed water quality analysis and other environmental parameters. Spatial WQI map in GIS will give exact idea about the water quality of nearby areas also, as we are using interpolation techniques to map WQ. 
P.C. Aneesh and Roy M Thomas

\section{ACKNOWLEDGEMENT}

The authors are thankful to $\mathrm{CPCB}$, India for providing the water quality data.

\section{REFERENCES}

[1] H. Boyacioglu, Development of a water quality index based on a European classification scheme, Water Sa., 33(1),2007, 101-106.

[2] B. Khalil, T. B. M. J. Ouarda, and A. St-Hilaire, Estimation of water quality characteristics at ungauged sites using artificial neural networks and canonical correlation analysis, J. Hydrol, 405(3-4),2011, 277-287.

[3] S.-M. Liou, S.-L. Lo, and S.-H. Wang, A generalized water quality index for Taiwan, Environ. Monit. Assess., 96(1), 2004, 35-52.

[4] N. M. Gazzaz, M. K. Yusoff, A. Z. Aris, H. Juahir, and M. F. Ramli, Artificial neural network modeling of the water quality index for Kinta River (Malaysia) using water quality variables as predictors, Mar. Pollut. Bull.,2012, DOI: 10.1016/j.marpolbul.2012.08.005.

[5] S. F. Pesce and D. A. Wunderlin. Use of water quality indices to verify the impact of Córdoba City (Argentina) on Suquía River, Water Res.,34(11),2000, 2915-2926.

[6] F. W. Kaurish and T. Younos, Developing a standardized water quality index for evaluating surface water quality, JAWRA J. Am. Water Resour. Assoc.,43(2),2007, 533-545.

[7] Bhargava DS, Use of a water quality index for river classification and zoning of the Ganga River, Environ Pollut (Ser B), 6, 1983,51-67.

[8] Bhargava DS, Saxena BS, Dewakar A, A study of geopollutants in the Godavary river basin in India, Asian Environment. IOS Press, Amsterdam,1998,36-59.

[9] Brown RM, McClelland NI, Deininger RA, Tozer RG, Water quality index-do we dare?, Water Sew Works,117(10), 1970, 339-343.

[10] Brown RM, McClelland NI, Deininger RA, O'Connor MF, A water quality index — crashing the psychological barrier. In: Indicators of environmental quality,1,1972,173-182.

[11] Dwivedi S, Tiwari IC, Bhargava DS, Water quality of the river Ganga at Varanasi, Inst Eng Kolkata,78,1997,1-4.

[12] Landwehr JM, Deininger RA, A comparison of several water quality indices. J Water Pollut Control Fed,48(5),1976,954-958.

[13] N. Fernández, A. Ramírez, and F. Solano. Physico-chemical water quality indices-a comparative review. Bistua Rev. la Fac. Ciencias Básicas., 2(1),2004, 19-30.

[14] Lakshmi E, Madhu G, An Assessment of Water Quality in River Periyar, Kerala, South India Using Water Quality Index, IOSR Journal of Environmental Science, Toxicology and Food Technology, 8(8-II), 2014,11-16.

[15] Kosha A. Shah, Geeta S. Joshi, Evaluation of water quality index for River Sabarmati, Gujarat, India, Appl Water Sci, 7,2017,1349-1358. 